\title{
Angažovaný Roman Jakobson a jeho cyrilometodějské dědictví
}

Jindřich Toman (ed.):

\section{Angažovaná čítanka Romana Jakobsona. Články, recenze, polemiky 1920-1945 a Moudrost starých Čechů.}

Praha: Karolinum 2017. 300 s.

ISBN 978-80-246-3673-3

1. Zdá se, že zájem o titánskou postavu Romana Jakobsona v poslední době neutuchá. Po dalším svazku jeho Selected Writings, o němž jsme referovali v tomto časopise (srov. VYKYPĚL 2014), a edici bojovné Moudrosti starých Čechů, kterou pronikavě analyzoval Jakub Sichálek (2016), ted' vydal přední jakobsonologický pracovník Jindřich Toman výbor Jakobsonových textů, který má Jakobsona představit jako angažovaného intelektuála, „který nosí své akademické zboží na trh veřejného mínění“ (Toman 2017, 9).

Výbor je rozdělen do několika oddílů, vymezených vždy jakýmsi heslem společným pro texty v oddíle obsažené. Každý oddíl i každý text pak je uveden koncízním editorovým komentářem. Předřazen je přitom Jakobsonův de facto programový text z roku 1937 o pojetí a úkolech vědecké publicistiky, odrážející dobový optimismus v tomto směru, dnes jen těžko myslitelný.

První oddíl přináší texty týkající se Jakobsona a avantgardy, datované zejména do 20 . let. Ty zjevně odrážejí jiný aspekt dobového optimismu určitých intelektuálů, totiž stran možností působení umění v sociálním dění, případně stran spolupráce vědy a umění. Zčásti ovšem jde o mladické nerozvážnosti (které Jakobsonovi ostatně vytýkal už Trubeckoj, srov. JAKоBSoN 1975, 313-314); vidíme tu ale také zřetelně fatalitu avantgardy, spočívající v boji na dvě strany, proti konzervativcům a proti stalinistům, v němž se ani Jakobsonovi neorientovalo snadno.

Další oddíl tvoří texty pod heslem nová věda, spadající zejména do první poloviny 3o. let. Nová věda je $\mathrm{z}$ formální stránky věda organizovaná, plánovaná a kolektivní, z funkční stránky pak věda společensky relevantní, přičemž společenská relevance pramení z toho, že nová věda je funkcionalistická či teleologická, ne kauzální, ptajíc se nač, ne proč. Takové pojetí vědy je také dobové a čteme je například i u Jakobsonova spolubojovníka z Pražského lingvistického kroužku (PLK) Viléma Mathesia, který - optimisticky, nebo, chcete-li, naivně - požaduje sociálně usměrňovat výběr badatelských témat, aniž by se pak sociálně usměrňovalo jejich řešení (srov. Mathesius 1933).

Následující oddíl, s texty zejména z druhé poloviny 30. let, má za heslo emancipaci. To je vlastně pokračování $v$ předešlém: nejdřív avantgarda nebo rovnou revoluce jako emancipace sociální, pak nová věda - „vědecká avantgarda“ - jako de facto jeden z aspektů sociální emancipace, a ted' přichází emancipace evropského východu a evropského středověku, totiž vlastně emancipace od evaluativních náhledů západního novověku, tedy buržoazní společnosti (tak pěknou sumou dostáváme épater le bourgeois v trojí formě). Sem patří i velké téma cyrilometodějství a jeho role v českých dějinách, o němž pojednáme ještě níže. 
Vrcholem bojovnosti jsou pak texty z posledního oddílu, spadající do první poloviny 40. let, tedy doby Jakobsonova amerického exilu. V nich čteme naléhavou obhajobu myšlenky první československé republiky, hájené zvláště proti Němcům. K nim se druží i post scriptum s Jakobsonovým pohnutým přípitkem české zemi z roku 1969 a knižní Moudrost starých Čechů z roku 1943 jako svého druhu přepjatá syntéza Jakobsonovy angažovanosti.

Knihu uzavírá pěkný editorův doslov, skicující a kontextualizující hlavní náměty a hesla otištěných Jakobsonových textů.

2. Na problémy Tomanovy edice (nejistá textová spolehlivost, nezřetelnost pojmu angažovanosti, nestejná hloubka editorových komentářů) upozornil už Říha (2018). My se chceme věnovat spíš námětům pro další práci, které kniha poskytuje.

Předně by bylo zajímavé podniknout stylisticko-argumentační rozbor Jakobsonových textů. Např́íklad jsou nápadná dekorativní epiteta dávaná autoritám, které Jakobson cituje na podporu svých tvrzení, nebo emfatické deklarace protivného stanoviska jako nevědeckého, ovšem kontrastované deklarací vědecké povahy stanoviska vlastního. Takové věci jsou nejspíš vysvětlitelné z dobového kontextu nebo jsou dokonce obecné, stála by ale za prozkoumání jejich míra u Jakobsona.

Zajímavá k bližšímu prozkoumání by byla rovněž otázka, zda politické aktualizace u Jakobsona po roce 1945 zmizely, př́padně se jen transformovaly. Zjevné je, že se staly méně bezprostředními, jako bylo i Jakobsonovo zapojení do veřejného života po roce 1945 méně bezprostřední. Asi bude mít pravdu editor, když píše v doslovu (srov. Toman 2017, 277-278), že Jakobson v Americe už v tomto směru neměl publikum (řečeno $\mathrm{z}$ jiného úhlu pohledu, v amerických novinách neměl známé a takové texty, jaké psával do novin v ČSR, by mu tam asi ani nevzali, nehledě vůbec např́klad na tlak za mccarthismu). Možná byl i méně optimistický nebo, chcete-li, méně iluzivní či rozumnější co do možností plánování a kolektivní práce (i když iluze o SSSR ve skutečnosti asi neměl nikdy, srov. VYKYPĚL 2013, 72, pozn. *). Ale chtělo by to právě bližší rozbor, nějaký druhý díl Angažované čítanky Romana Jakobsona.

Konečně obecně se klade otázka, zda je instrumentalizace nebo ideologizace nebo angažovanost vědy vždy zásadně špatná, př́ípadně zda se jí lze vůbec ubránit. Domníváme se v tomto ohledu jednak, že ze sociální determinace vědy (a to nejen humanitní, ale i exaktní!) se nelze vymanit, jednak, že záleží na tom, pro co se věda angažuje: každý jistě uzná, že angažovat se např́iklad pro prvorepublikové Československo jako Jakobson je lepší než angažovat se např́klad pro nacionální socialismus.

Co se nám ale zdá nad jiné lákavé, je otázka, která je s tématem veřejné angažovanosti přirozeně spojená, totiž otázka vlivu Romana Jakobsona. Ten je, myslíme, málo pojednaný obecně i v českém vědeckém kontextu konkrétně. Matějka (2002-2003) psal např́íklad o vlivu Jakobsona na Arna Nováka. Tomanova antologie ale ukazuje na jeden zvlášt nabádavý př́́klad, totiž Jakobsonovo pojetí cyrilometodějské misie a českého církevněslovanského písemnictví. O něm chceme na tomto místě přídavkem pojednat trochu blíže, protože od Jakobsona je možno datovat v české filologii něco jako hodnotící převrat v této otázce. 
3. Nepřetržitou existenci církevněslovanské liturgie a písemnictví v Čechách 10.-11. století, př́padně i jejich jistý rozkvět a význam uznávali či připouštěli někteří autoři už dříve (srov. KROFTA 1947, 108-122). Co ale přineslo vystoupení badatelů kolem PLK, včetně Jakobsona, v 30. letech nového, bylo to, že otázka po roli staroslověnské kultury v Čechách byla zahrnuta do otázky vzniku staročeského písemnictví: nejen že staroslověnská kultura ve středověkých Čechách měla přestat být onou Jagićovou (a Novotného) pokojovou květinkou, ale byla jí dokonce přisouzena podněcující role při vzniku staročeského písemnictví - ideově přinesla požadavek národního jazyka a věcně přispěla k př́pravě a vybroušení potřebných jazykových prostředků. Teze, že české církevněslovanské písemnictví - jako jakýsi ponorný proud - mělo iniciační vliv na vznik českého písemnictví, přitom představovala skutečné novum. Jak upozornil Krofta $(1947,110)$, náznakem sice postuloval tuto roli české církevní slovanštiny už Tomek, který, aniž by to ale blíže rozvedl, vyslovil názor, že slovanská liturgie podnítila překlad bible do češtiny (srov. poprvé ToMEK 1864, 86-87 a pak i v dalších vydáních), přičemž, dodejme, totéž - bez odkazu na autora - opakoval Bayer $(1878,38)$. Ale Jakobson, Havránek, Weingart ani jiní diskutující, o nichž ještě bude řeč, tyto své předchůdce zřejmě neznali nebo alespoň necitovali.

Pokud jde o původcovství zmíněné teze, zdá se na první pohled, že iniciátorem byl právě Jakobson, který byl jednak obecně protipozitivisticky naladěn (a právě čeští pozitivisté byli skeptičtí vůči významu českocírkevněslovanské kultury) a naopak otevřen různým odvážným explikativním i aktualizujícím konstruováním, jednak konkrétně docela těžce nesl despekt, s nímž Západ pohlížel na Východ, a snažil se proto ukázat přednosti a výkony Východu, Západem neprávem ignorované. Nejdřív ve své knížce o nejstarších českých duchovních písních z roku 1929 a potom v textu o staročeském verši z roku 1935 vyzdvihuje význam české církevněslovanské literatury (srov. JAковson 1929, 25-27; 1935, 50). Pak v textu z roku 1936 tento význam rozšiřuje v tom smyslu, že česká církevněslovanská literatura tím, že ukázala, že je možné slovesně tvořit v domácím jazyce, vytvořila precedens, na který navázalo staročeské písemnictví (srov. JAKoBSON 1936, 6-12); přibližně totéž potom opakuje i v dalších následujících textech (srov. LEHÁr 1995). Nicméně iniciátorská role Jakobsona tu zřejmě nebyla úplně výlučná. Přibližně ve stejné době totiž o tom, že českocírkevněslovanské písemnictví podnítilo vznik písemnictví staročeského, čteme u Miloše Weingarta. Ve své práci o první staroslověnské václavské legendě Weingart píše ještě neostře o zakladatelském úkolu církevněslovanské literatury a liturgie (srov. WEINGART 1934, 1031). V úvodu k textu, v němž německy resumuje právě řečenou práci, pak už přímo říká, že čeština a česká literatura se zrodily na základech položených církevněslovanskou kulturou (srov. WEINGART 1935, 154-155). Ještě určitěji se nakonec vyjadřuje v prvním díle své staroslověnské mluvnice, kde píše, že staroslověnština připravila půdu pro českou literaturu, která díky tomu začala dřív než u většiny slovanských i jiných evropských národů (srov. WEINGART 1937, 95).

O prvenství tu asi nelze rozhodnout. Weingartův text z roku 1935 vyšel ve třetím čísle pátého ročníku Prager Rundschau, jehož redakční uzávěrka byla 20. 5. 1935. Jakobson svůj výše zmíněný text z roku 1936 původně přednesl v PLK 29. 4. 1935. Avšak Weingart na jeho 
přednášce nebyl (srov. ČERMÁK et al. 2012, 166-167). Nejspíš se jednalo o paralelní domýšlení výchozích úvah, formulovaných ve společném diskusně-publikačním milieu. Nicméně tím, kdo podnítil vůbec vznik takového milieu a položení takových otázek, byl nejspíš skutečně Jakobson (srov. přibližně v tomto smyslu i KuRZ 1939, 233). U Jakobsona mohl přitom být negativním podnětem k onomu domýšlení názor Trubeckého vyslovený v dopise ze 14 . 3. 1935: v něm Trubeckoj mimo jiné reagoval na Jakobsonův text z prvního čísla Slova a slovesnosti (JAKоBSON 1935) a v té souvislosti napsal, že církevněslovanská tradice v Čechách existovala v podobně reliktů a nikoli jako hybná síla (srov. JAKOBson 1975, 327). To mohlo Jakobsona přimět jednak $\mathrm{k}$ promýšlení obhajoby své teze, jednak $\mathrm{k}$ jejímu rozšíření postulátem prospektivní, nikoli jen reliktní povahy role staroslověnštiny v českém středověku. Pozitivní podnět pak pro Jakobsona mohla představovat Lavrovova monografie o Cyrilovi a Metodějovi z roku 1928, z níž Jakobson později cituje právě otázku, Lavrovem nadhozenou (srov. LAVRov 1928, 207), zda „časný vznik a rozkvět české literatury v mateřštině proti zpožděnému vývoji polskému není v souvislosti s působivou tradicí církevněslovanskou“ (srov. JAKoBson 1938, 237). Lavrova a př́slušné místo z něho ovšem přirozeně mohl znát i Weingart. Konečně by za prověření možná stálo, co píše Uhde (2013, 61), totiž, že Frank Wollman v 50. letech tvrdil, že před válkou Jakobsonovi svěřil „několik odborných teorií a nápadů“, které pak Jakobson uplatnil a jejich skutečného autora zatajil.

At tak či onak, můžeme říct, že roli jakéhosi propagátora pojednávané teze, př́padně toho, kdo „syntetizoval“ obecně skicujícího Jakobsona a explicitněji formulujícího Weingarta, sehrál Bohuslav Havránek. Poučný je tu nejdřive Havránkův programový úvod, ostatně s dalším textem nespojitý, $\mathrm{k}$ recenzi Vajsových a Vašicových edic václavských a ludmilských legend a Jakobsonova pojednání o nejstarších českých duchovních písních, kde se jako novum vyzdvihuje zdůraznění síly českocírkevněslovanského písemnictví (srov. HAVRÁNEK 1931, 192-193), a pak Havránkova polemika s Weingartem, kde Havránek zase cituje zmíněné Jakobsonovo pojednání na důkaz, že původcem onoho nova je Jakobson a ne Weingart (srov. HaVRÁNEK 1935, 360-361; WeInGART 1936, 240-241; HAVRÁNEK 1936a, 254-255). Tento ostrý spor o původcovství odráží napjatou atmosféru po známém rozchodu Weingarta s PLK na podzim 1934 (srov. k němu nověji SLÁDEK 2015, 208-217), a zdál by se tak svědčit proti Weingartově vlivu na Havránka. Nicméně spor sám se jednak netýkal postulátu podněcujícího vlivu staroslověnštiny na časný vznik českého písemnictví, jednak svědčil o Havránkově intenzivní recepci Weingartových textů. Po Weingartově předčasné smrti, která navíc př̀šla v pohnuté době mezi Mnichovem a březnem 1939, pak Havránek napíše o Weingartovi uznalé vzpomínkové texty, byt nezakrývající názorové rozdíly (srov. HAVRÁNEK 1939; 1949), a částečně ho ocení i v jednom poválečném dopise Jakobsonovi (srov. HAVRÁNKovÁ - ToMAN 2001, 68-69). Havránkova zmíněná „syntéza“ pak má dvojí složku: obecnou tezi o nástupnictví češtiny po staroslověnštině ve funkci domácího spisovného jazyka a konkrétní ukázání prostředků, které čeština od staroslověnštiny pro toto fungování převzala, totiž jisté části náboženské terminologie (srov. HAVRÁNEK 1936b, 11, 15). Po válce nakonec Havránek ještě publikuje „kanonickou“ formulaci vztahu staroslověnštiny a staré češtiny, která následně vahou jeho autority, ač ne bez důvodů a argumentace, v české filolo- 
gii zobecní (srov. HAVRÁNEK 1951, 211; 1963, 94, 334). Přitom se ovšem můžeme také domnívat, že zmínka o vlivu staroslověnštiny na vznik českého písemnictví ve Weingartově mluvnici staroslověnštiny (srov. WEINGART 1937, 95), tedy na edukačně exponovaném místě, jistě rovněž nezůstala bez vlivu na další replikaci tohoto názoru ve filologické komunitě.

Vliv okruhu kolem PLK můžeme konečně, jak se zdá, konstatovat také u historika Václava Chaloupeckého. Ve své syntetické skice českých raněstředověkých dějin, vzniklé někdy v druhé polovině roku 1936 (srov. DucháčEK 2015, 311-312), vyzdvihuje Chaloupecký význam církevněslovanského písemnictví, ale nechává je ještě končit s koncem 11. století a bez dalšího vlivu, jen vágně zmiňuje, že doba církevněslovanského písemnictví položila základy české vzdělanosti, jazyka a literatury (srov. CHALOUPECKÝ 1937, 619 a také DucháčEK 2015, 312-313 k Jakobsonovu „instrumentalizujícímu“ čtení Chaloupeckého textu, otištěnému ted' i u Tomana, srov. Toman 2017, 77-80). V monografii o pramenech Kristiánovy legendy pak už Chaloupecký přímo píše, že slovanská bohoslužba sice v českých zemích zanikla, ale jí vytvořené kulturní hodnoty, zejména kulturní jazyk a národní povědomí, přetrvaly, a také, že slovanské křestanství (rozuměj církevní slovanština) je dodnes podkladem náboženské, církevní i státní terminologie u západoslovanských národů (srov. CHALOUPEckÝ 1939, 402-403, 423). Právě v polovině 30. let Chaloupecký přitom zjevně navázal užší kontakt s PLK: 24. 2. 1936 tam přednášel na téma Církevně-slovanská tradice u nás, přičemž o pokračování jeho přednášky, které se nakonec neuskutečnilo, se pilně jednalo (srov. ČERMÁK et al. 2012, 650, 656, 670; HAVRÁNKovÁ 2008, 149, 201), a ve výše zmíněných textech cituje Jakobsona (1929) a Havránka (1936b) (srov. CHALOUPECkÝ 1937, 637, 1939 passim). Jakobson pak po válce píše Chaloupeckému nadšené dopisy, v nichž mezi jiným vyzdvihuje jeho pojetí české církevní slovanštiny (srov. MoRÁvková 1997, 62-70). Hodné povšimnutí přitom je, že Chaloupeckého pojetí se v české historiografii neprosadilo. Už Krofta (1947) je zmírňuje, a pak po roce 1948 byl Chaloupecký př́liš buržoazní, než aby jeho názory zobecněly (srov. PACHTA 1950, 92-93; DucháčEK 2015, 421). Nakonec se od 60. let jako většinové mezi historiky prosadilo stanovisko marginalizující význam české církevněslovanské kultury. Mareš (2000, 478) to vysvětloval tím, že historikům je jazykovědná argumentace vzdálenější, ale hlavně zde asi působí okolnost, že historici obecně spíš zůstávají věrni svému pozitivistickému (či empiricko-kritickému) metodologickému fundamentu. Navíc konkrétně v našem případě tu spiritus agens byl František Graus, př́liš sekulární na to, aby měl církevněslovanské věci za důležité, a v podobném duchu pak pokračoval jeho žák a přední postava české medievistiky Dušan Třeštík. Ovšem ani u „protipř́lkladư“, tedy poválečných českých historiků, kteří považují církevně slovanskou kulturu Čech 10.-11. století za významnou, „filologickou“ tezi o její podněcující roli při vzniku staročeského písemnictví nenajdeme (srov. TUREK 1963, 17-19, 186-189, 259-260; 1982; 171-173, 218-219; 1988, 42, 110, 140; KAVKA 1964, 116-119).

(Text byl napsán s podporou grantu Staroslověnské dědictví v staré češtině Grantové agentury ČR, č. 18-02702S.) 


\section{LITERATURA}

ČERMÁK, Petr - PoetA, Claudio - ČERMÁK, Jan. 2012. Pražský lingvistický kroužek v dokumentech. Praha: Academia.

DucháčEK, Milan. 2015. Václav Chaloupecký. Hledání československých dějin. Praha: Karolinum. HAVRÁNEK, Bohuslav. 1931. Recenze: J. Vajs (ed.): Sborník staroslovanských literárních památek o sv. Václavu a sv. Lidmile (Praha 1929), J. Slavík: Svatý Václav a slovanskélegendy (Praha 1929), J. Vašica: De sancto Venceslao in documentis litterarum palaeoslovenicis (Olomucii 1930), R. Jakobson: Nejstarší české písně duchovní (Praha 1929). Časopis Matice moravské 55, 192-215.

HAVRÁNEK, Bohuslav. 1935. Recenze: M. Weingart: První česko-církevněslovanská legenda o svatém Václavu (Praha 1934), M. Weingart: La première légende de Saint Venceslas, écrite en vieux slave et d'origine tchèque (Prague 1934). Časopis Matice moravské 59, 341-362.

HAVRÁNeK, Bohuslav. 1936a. Kritikův doslov. Časopis Matice moravské 60, 243-256.

HavráNek, Bohuslav. 1936b. Vývoj spisovného jazyka českého. In: Hujer, Oldřich, ed. Československá vlastivěda. řada II. Spisovný jazyk český a slovenský. Praha: Sfinx, 1-144.

HAVRÁneK, Bohuslav. 1939. Miloš Weingart zum Gedächtnis. Slavische Rundschau 11, 43-45.

HAVRÁNEK, Bohuslav. 1949. Deset let od smrti Miloše Weingarta. Lidové noviny 57(9), 12.1. 1949, 3.

Havránek, Bohuslav. 1951. O vývoji českého jazyka. In: Havránek, Bohuslav - JeduičKA, Alois. Česká mluvnice. Praha: Slovanské nakladatelství, 205-227.

HAVRÁNeK, Bohuslav. 1963. Studie o spisovném jazyce. Praha: Nakladatelství ČSAV.

Havránková, Marie (ed.). 2008. Pražskýlingvistický kroužekv korespondenci. Praha: Academia.

Havránková, Marie - Toman, Jindřich. 2001. Quadrilog. Bohuslav Havránek, Zdeňka Havránková, Roman Jakobson, Svatava Pírková-Jakobsonová. Vzájemná korespondence 1930-1978. Praha: Karolinum.

CHALOUPECkÝ, Václav. 1937. Počátky státu českého a polského. In: ŠustA, Josef, ed. Dějiny lidstva od pravěku k dnešku. Díl třetí: Základy středověku. Praha: Melantrich, 589-638.

Chaloupeckŕ, Václav. 1939. Prameny X. století legendy Kristiánovy o svatém Václavu a svaté Ludmile. Praha: Národní výbor pro oslavu svatováclavského tisíciletí.

Jakobson, Roman. 1929. Nejstarši české písně duchovní. Praha: Ladislav Kuncír.

JAKOBSON, Roman. 1935. K časovým otázkám nauky o českém verši. Slovo a slovesnost 1, 46-53. JAKoBson, Roman. 1936. Úvahy o básnictví doby husitské. Slovo a slovesnost 2, 1-21.

JAKoBSON, Roman. 1938. Význam ruské filologie pro bohemistiku. Slovo a slovesnost 4, 222-239. Jakobson, Roman (ed.). 1975. N. S. Trubetzkoy's Letters and Notes. The Hague - Paris: Mouton. KavkA, František. 1964. Dějiny Československa do roku 1437. Praha: Státní pedagogické nakladatelství.

KROFTA, Kamil. 1947. Naše starélegendy a začátky našeho duchovního života. Praha: Jan Laichter. KuRz, Josef. 1939. Práce profesora Miloše Weingarta z církevní slovanštiny a ze slovanského jazykozpytu. Časopis pro moderní filologii 25, 225-249.

LAvrov, Petro. 1928. Kyrylo ta Metodij v davn'o-slov'jans'komu pis'menstvi. Kyjiv: Ukrajins'ka Akademija Nauk. 
LEHÁR, Jan. 1995. Roman Jakobson: Moudrost starých Čechů (Nedokončená polemika o smysl českých dějin). Česká literatura 43, 39-56.

MAREš, František, Václav. 2000. Cyrilometodějská tradice a slavistika. Emilie Bláhová, Josef Vintr, eds. Praha: Torst.

MATĚjKA, Ladislav. 2002-2003. Arne Novák a turbulentní Roman Jakobson. Sborník prací filozofické fakulty brněnské univerzity V 5-6, 149-154.

Mathesius, Vilém. 1933. Aktualisace universit. Čin 5, 273-277.

Morávková, Alena (ed.). 1997. Roman Jakobson - z korespondence. Praha - Litomyšl: Paseka.

PACHTA, Jan. 1950. Pekař a pekařovština v českém dějepisectví. Brno: Rovnost.

Ř́́HA, Jakub. 2018. Více angažovanosti. [28.1. 2019]. Dostupné z http://i-kanon.cz/2018/01/04/ vice-angazovanosti/

SichÁLEK, Jakub. 2016. Recenze: R. Jakobson: Moudrost starých Čechů (Praha - Červený Kostelec 2015). [28. 1. 2019]. Dostupné z http://www.ipsl.cz/index.php?id=881\&menu=echa\&sub=echa\&str=echo.php

SLÁDEK, Ondřej. 2015. Jan Mukařovský. Život a dílo. Brno: Host.

Toman, Jindřich (ed.). 2017. Angažovaná čítanka Romana Jakobsona. Praha: Karolinum.

Tomek, Vácslav Vladivoj. 1864. Děje Království českého. 3. vyd. Praha: František Řivnáč.

Turek, Rudolf. 1963. Čechy na úsvitě dějin. Praha: Orbis.

TuREK, Rudolf. 1982. Čechy v raném středověku. Praha: Vyšehrad.

Turek, Rudolf. 1988. Počátky české vzdělanosti. Praha: Vyšehrad.

Uhde, Milan. 2013. Rozpomínky. Co na sebe vím. Praha: Torst - Brno: Host.

VYKYPĚL, Bohumil. 2013. Skizzen zur linguistischen Historiographie. München: Lincom.

VYKYPĚL, Bohumil. 2014. Recenze: R. Jakobson: Selected Writings IX/1-2 (Berlin - Boston 2013-2014). Linguistica Brunensia 62 (2), 139-140.

Weingart, Miloš. 1935. Die Anfänge der tschechischen Kultur und die I. tschechisch-kirchenslavische Sankt Wenzelslegende. Prager Rundschau 5, 143-171.

Weingart, Miloš. 1934. První česko-církevněslovanská legenda o svatém Václavu. In: GuTH, Karel - Kapras, Jan - Novák, Antonín - Stloukal, Karel, eds. Svatováclavský sborník. I. Praha: Národní výbor pro oslavu svatováclavského tisíciletí, 863-1088.

Weingart, Miloš. 1936. V ČMM 1935, str. 341-362, vyšel posudek... Časopis Matice moravské 60, 229-243.

Weingart, Miloš. 1937. Rukovět' jazyka staroslověnského. I. Praha: Didaktický kruh Klubu moderních filologů.

Bohumil Vykypěl

Czech Language Institute of the CAS, v. v. i. Czech Republic

Veveří 97, 602 oo Brno

vykypel@iach.cz

Toto dílo Ize užít v souladu s licenčními podmínkami Creative Commons BY-NC-ND 4.0 International (https://creativecommons.org/licenses/by-nc-nd/4.0/legalcode). Uvedené se nevztahuje na díla či prvky (např. obrazovou či fotografickou dokumentaci), které jsou v díle užity na základě smluvní licence nebo výjimky či omezení př́slušných práv. 